\title{
The Effect of Storytelling Assisted by Pop-Up Media to Improve Language Development Skills and Attitude of Opinion
}

\author{
Usep Kustiawan, Evania Yafie
}

Department of Primary School and Preschool Education, State University of Malang, Malang, Indonesia

Corresponding Author: Evania Yafie

\begin{abstract}
This study aims to find out the effect of storytelling assisted by pop-up media to improve language skills and attitude of opinion in children aged 5-6 years. This study uses a quantitative pre-experimental research design with one group pre-test-post-test design without a control class. This research is conducted in TK Laboratorium UM, Malang City; with the population of the students of Class B. The data analysis used in this study includes normality test, homogeneity test, and hypothesis test. According to research and data analysis that has been carried out and the results obtained in this study, it can be concluded that there is a significant effect between storytelling assisted by pop-up media to improve language skills and the attitude of opinion in early childhood.
\end{abstract}

Keywords: storytelling, pop-up media, language development skills, attitude of opinion

\section{INTRODUCTION}

Childhood is the most important period in the stage of language development because at this age the growth and development of children's language reaches the most rapid condition (1). The development of language in children generally emphasizes the sequence of listening, speaking and then to the stages of reading and writing. This development must be carried out in a balanced manner in order the children get optimal development (2). Language development in children is also important so that children can use and express their thoughts using the right words
(3). Language development in early childhood is very important because language as the basis of the children's other abilities to improve (4). Children continue to need to be trained to think and solve problems through their language (5).

One aspect of development that is important to be stimulated is the aspect of language development. Language development is a basic ability that needs to be possessed by children. This development consists of several stages according to the age and characteristics of the children's development. Speaking skill is a very basic and important ability in establishing social relationships (6). Children should be encouraged to speak well. Speaking skills are a necessity, thus, children can become part of their social group while balancing various developments at the same time (7). Childhood is a very important time in learning to speak (8). Because by talking, children will actively seek meaning and will find ways to communicate with other children. If the children experience delays in language development, they will also get obstacles in absorbing information (9).

The development of children's speech in general often experiences obstacles where the children's vocabulary is limited which can be seen when children converse using short sentences, as well as articulation and the sound of the language spoken by children is sometimes less clear (10). Mastery of speaking skills can be obtained through the provision of 
stimulation to children. In the process of speaking skills, early childhood needs to be stimulated such as training children to speak a good and correct language (11) in order for children can express ideas, thoughts, feelings or things they want, thus, the children will have no difficulty in expressing what they feel. The development of this speaking skills will continue to develop according to the age of the children; therefore, the earlier the children are stimulated by their speaking skills, the speaking ability will develop well (12).

Good language development in children can also affect their skills in expressing opinions (13). It is important for children to have the courage to have an opinion so that they are able to convey their ideas and thoughts on the things that have been learned (14). Children will find it easier to gain new knowledge by building their own knowledge through discussions that occur when they have the courage to express their opinions (15). This ability makes children who want to express something based on the knowledge that has been absorbed. The ability to think makes children able to learn to accept feelings (16).

Expressing an opinion is essentially a process of conveying thoughts or feelings by one person to another. Thoughts can be ideas, information, opinions, and others that arise from their mind. Children who often express opinions are usually considered as active children both during learning activities in class and in their daily lives when at home (17).

Stimulation that can be given to children so that they can develop language skills and the courage to express their opinions can be done by providing storytelling stimuli(Sustainable \& Sustainable, 2018). Storytelling is an active activity to convey stories in a structured and complete way. Storytelling has many uses in a child's primary education. Storytelling provides a conceptual framework for thinking, which causes children to form experiences into a whole that can be understood by children (19). Storytelling allows them to mentally map their experiences and see pictures in their heads (20). In the storytelling process, there is an interaction between the storyteller and the audience (21). The most important thing in the storytelling process is the process that occurs (22). In the process of storytelling, there is communication between the storyteller who is a teacher and the audience in the form of children (Interactive Books: Playful Media before Pop-Ups-Jacqueline Reid-Walsh-Google Books, nd). Because storytelling activities are important for children, they must be packaged in such a way that they are interesting (24). One way that can be used is pop-up media.

Pop-up book is a media in the form of a book with movable parts or has threedimensional elements and provides a more interesting visualization of the story, starting from the display of images that can move when the page is opened (Guidance, 2020). Pop-up books can be designed according to the material needs or themes in storytelling that will be conveyed to children (26). One of the advantages of pop-up books is the visualization of images to make them more attractive. Pop-up books are more interesting because they can visualize concepts in lessons into 3-dimensional images. Pop-up book display is one of the advantages because it looks unique and different from other two-dimensional learning media (27). Based on the background explanation above, this research aims to find out the effect of storytelling assisted by pop-up media to improve language development skills and an attitude to have an opinion.

\section{THEORITICAL REVIEW}

\section{A. Children's Language Development}

Each stage of language development requires appropriate stimulation and situations that allow children developing their language skills. They need an opportunity to be able to talk, discuss, and formulate hypotheses and synthesis. Language learning in early childhood must be in a situation where it allows children to 
have the opportunity to immerse themselves, be actively involved, get real examples, get opportunities and responsibilities, practice and guess, and get the right response from adults (28)

In addition, things that must be considered in the development of children's language are the stages of all aspects of the children development, because at this age, there is rapid development in various aspects of children's development which will greatly determine the level of optimization of the next development (29). Dimensions and indicators of children's language development can be seen in the following table:

Table I: Dimension and Indicator of Children's Language Development

\begin{tabular}{|l|l|}
\hline Dimension & \multicolumn{1}{|c}{ Indicator } \\
\hline Receptive (30) & Listening to other people's words (mother tongue or other language (Permendikbud No. 137 of 2014, nd) \\
\cline { 2 - 3 } & Understanding two commands given at the same time (Permendikbud No. 137 of 2014, nd) \\
\cline { 2 - 3 } & Understanding the story that is read (Permendikbud No. 137 of 2014, nd) \\
\cline { 2 - 3 } & Recognizing the sounds of animals/objects around them (Permendikbud. No. 137 of 2014, nd) \\
\hline Literacy (33) & Repeating simple sentences (Permendikbud No. 137 of 2014, nd) \\
\cline { 2 - 3 } & Answering simple questions (Permendikbud No. 137 of 2014, nd) \\
\cline { 2 - 3 } & $\begin{array}{l}\text { Expressing feelings with adjectives (good, happy, naughty, stingy, kind, brave, good, bad, etc. (Permendikbud No. 137 of } \\
\text { 2014, nd) }\end{array}$ \\
\cline { 2 - 3 } & Expressing opinion to others (Permendikbud No. 137 of 2014, nd) \\
\cline { 2 - 3 } & Stating the reason for something desired or disapproval (Permendikbud. No. 137 of 2014, nd) \\
\cline { 2 - 3 } & Saying familiar words (Permendikbud No. 137 of 2014, nd) \\
\cline { 2 - 3 } & Telling stories/fairy tales that have been heard (Permendikbud No. 137 of 2014, nd) \\
\cline { 2 - 3 } & Recognizing written symbols(Permendikbud No. 137 of 2014, nd) \\
\cline { 2 - 3 } & Making meaningful doodles (Permendikbud No. 137 of 2014, nd) \\
\cline { 2 - 3 } & Imitating letters (Permendikbud No. 137 of 2014, nd) \\
\hline
\end{tabular}

\section{B. Dare to Deliver Opinion}

Cawood (2011) argues that the skill of expressing an opinion is a picture of the expression of thoughts, feelings, needs, and rights that a person has in a direct, honest, and appropriate manner without any unreasonable anxiety but accompanied by the ability to be able to accept the feelings or opinions of others and not deny the rights them in expressing their thoughts and feelings. Other opinion according to Dietrich et al. (1992) that opinion is one of the activities that must exist in student learning activities, student activities expressing opinions are classified as oral activities, expressing opinions is one of reflecting active students in the learning process in class.

\begin{tabular}{|l|l|}
\multicolumn{2}{|c}{ Table II: Dimension and Indicator of Dare to Deliver Opinion } \\
\hline \multicolumn{5}{|c|}{ Dimension } & \multicolumn{1}{c}{ Indicator } \\
\hline Clarity of Expressing Opinions (38) & Speech Accuracy (39) \\
\cline { 2 - 2 } & Appropriate Placement of Pressure, Tone, Joint, and Duration (39) \\
\cline { 2 - 2 } & Word choice (Diction) (39) \\
\cline { 2 - 2 } & Conversation Target Accuracy (39) \\
\hline Able to communicate opinion (38) & Conformity of opinion with the material being taught (40) \\
\cline { 2 - 2 } & Smoothness (40) \\
\cline { 2 - 2 } & Bravery (40) \\
\cline { 2 - 2 } & Clarity of expression of opinion (40) \\
\cline { 2 - 2 } & Confusion of ideas/ideas (40) \\
\hline The content of the ideas conveyed is logical (38) & Able to understand the situation (41) \\
\cline { 2 - 2 } & Planning what will be disclosed regarding the situation (41) \\
\cline { 2 - 2 } & Reveal what has been understood (41) \\
\cline { 2 - 2 } & Reviewing what has been said (41) \\
\hline
\end{tabular}

Expressing opinion means expressing ideas or conveying thoughts verbally. In addition, the ability to argue is a person's desire to express something based on his knowledge and thoughts. The ability to think can also train students to be able to think critically and be skilled in speaking (36). A person's language reflects his thoughts; the more skilled a person speaks the brighter and clearer his way of thinking. Skills can be acquired and mastered by way of practice and a lot of practice (Tarigan, 
1980; Kasman et al., 2014). Therefore, having an opinion can train students to be brave to speak and argue in public, especially in front of their friends and thus the ability to think apart from being able to develop students' ways of thinking can also develop their speaking skills. The ability to express opinions can be measured through the following dimensions and indicators.

\section{Pop-Up Assisted Storytelling}

A pop-up is a card or book that when opened can display a 3-dimensional or embossed shape (42). Reid-Walsh (2012) defines that a pop-up book is a book that has moving parts or has three-dimensional elements. Pop-up book media is quite attractive because it is supported by threedimensional visualization, and also a more dimensional visual display that makes it more real with the surprises given to each page.

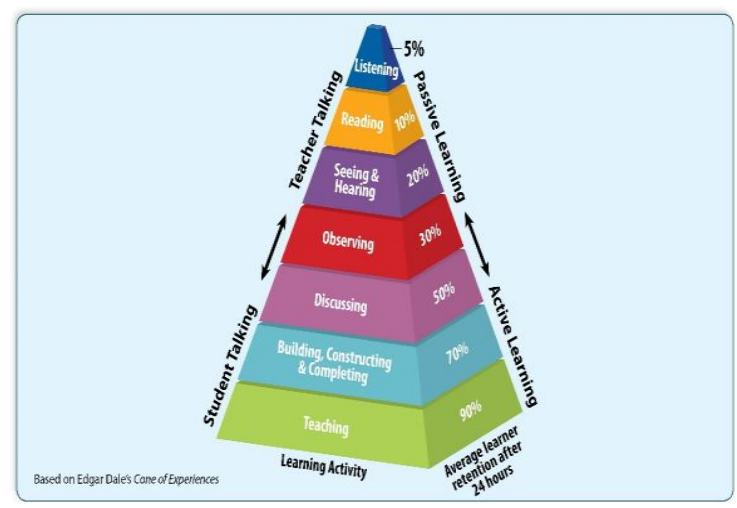

Fig1: Edgar Dale Experience Cone

Pop-up book learning media can be adapted to the characteristics of children's development according to their age. At this stage of development, children are able to connect new concepts with old concepts. Children will find it easier to do creative writing activities if the teacher provides artificial objects that are designed according to the child's experience. Pop-up book can be used as an alternative learning media that is able to arouse children's imagination and is a practical medium both in use and manufacture, in which only need to make an image pattern on paper, then, it is cut out and pasted on cardboard, the pop-up book is ready to use. Picture patterns can be made at will or adapted to the experience of students.

Pop-up books as one of the visual media can ease students to understand something abstract to be more concrete. According to Heo et al (2011), children in learning will be more successful if it is adjusted to the stage of cognitive development. Based on this theory, elementary school age children are in the concrete operational stage of age (7-11 years). At this stage, children can use operational thinking to understand concrete events. To help students understand concrete events, media is needed that can visualize these events. In this study, learning media in the form of pop-up books are used to help students understand the concept of the shape of the earth's surface.

According to Sabuda (accessed at www.robetsabuda.com on June 29, 2021) there are several kinds of pop-up techniques, including the following.

1. Transformation: a display form consisting of pop-up pieces arranged vertically

2. Volvelles: a form of display that uses the circle element in its manufacture

3. Peepshow: a view that is composed of a series of stacks of paper stacked together to create the illusion of depth and perspective

4. Pull tabs: a sliding paper tab or shape that is pulled and pushed to show a new image movement।

5. Carousel: this technique is supported by ropes, ribbons or buttons which when opened and folded back form a complex object

Boxes and cylinders: Box and cylinder or box and cylinder are the movement of a cube or tube that moves up from the center of the page when the page is opened. There are several pop-up techniques that can be used as the basis for making pop-up books. In making this pop-up book, the researcher uses transformations technique. 


\section{1) The Process of Organizing Storytelling Assisted by Pop-Up Media}

The storytelling activities focus more on the process carried out. In order for storytelling activities to be conveyed interestingly, media is needed. In this storytelling activity, the media used is popup media. In the implementation process, the stage of storytelling assisted by pop-up media consists of 3 parts which are the opening, the core, and the closing sourced from Geisler's theory (1997).

\section{a) Opening}

At the beginning of the activity, the teacher will attract the children's attention with an activity that requires concentration. The activity can be a game that involves the brain. Like guessing and games that require concentration. In this activity, the teacher also introduces the pop-up media that will be used. The introduction can include the title, the characters in the story, the time, and the setting in which the story takes place. The teacher also provides opportunities for students to observe the pop-up media that will be used. In the opening activity, eye contact needs to be made so that the children feel they are being cared for and invited to interact.

\section{b) Core}

The next activity is the core activity, namely storytelling. The storyteller will present the story by paying attention to words, body gestures, and sound play, thus, it displays a visual image in the minds of the children as the audience. The story that will be given is one story title that will be given for one day. The intensity of giving stories once and a day is associated with the experiences that have been passed by the teacher at the school that children can remember only one material or theme of the lesson requiring 4 to 6 meetings. Therefore, giving stories once and a day is to avoid bias of influences other than storytelling treatment, because the development of children at that age is very fast.

\section{c) Closing}

In the closing activity, there is an opportunity for children to repeat some of the dialogue sentences contained in the story. The children are asked to express his feelings about the story that has been read and express his opinion along with reasons why they can have that opinion. The teacher can also ask questions related to the story and ask the children to take turns answering.

\section{RESEARCH METHOD}

The research method used in this research is the experimental method. This study belongs to the Pre-Experimental type with a one group pre-test-post-test design. In this type of research, there is no control class and the sample is not taken at random, but the sample used is an ordinary class without changing the existing structure.

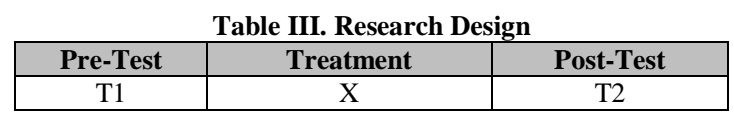

\section{Information:}

$\mathrm{T} 1=$ Pre-test is given before the learning activity takes place

$\mathrm{T} 2=$ The final test (post-test) is given after the activity takes place

$\mathrm{X}=$ Learning treatment uses the concept attainment learning method

The population used in this study were group B children in TK Laboratrium UM Malang City, amounting to 55 students consisting of 3 classes. Due to the number of populations below 100, the total sampling technique was used. Data collection techniques used the initial test (pre-test) and the final test (post-test). Pre-test was given before treatment. After the pre-test was done, the students were given treatment and then given a post-test.

\section{A. Normality test}

The normality test is used to determine whether the data population is normally distributed or not. The data is normally distributed if the significant value is $>0.05$, but, if the significant value is < 0.05 that means the data is not normal. The formula used is: 


$$
x^{2}=\sum \frac{(f o-f e)^{2}}{f e}
$$

$\mathrm{X} 2$ = value of chi squared

$\mathrm{Fo}=$ frequency of observations

$\mathrm{Fe}=$ theoretical frequency/expectations

\section{B. Homogeneity Test}

The homogeneity test is carried out by means of the largest variance compared to the smallest variance, it is used to find out several variants of the data population are the same or not, as a test criterion if the significant value is more than 0.05 then it can be said that the variance of two or more data groups is the same, the calculation for homogeneity test in this study using Chi Square.

\section{Hypothesis Test}

The hypothesis test used is using the t-test pre-test post-test one group analysis formula as follows:

\section{Information:}

$$
\mathrm{T}=\frac{M D}{\sqrt{\frac{\sum x^{2} d}{N(N-1)}}}
$$

MD = Mean of difference between pretest and post-test

$\mathrm{Xd} \quad=$ Deviation of each subject

$\mathrm{x}^{2} \mathrm{~d}=$ Sum of squared deviation

$\mathrm{N} \quad=$ Subject panda sample

d.b. = determined by $\mathrm{N}-1$

\section{RESULT}

\section{A. Normality Test Results}

\begin{tabular}{|c|c|c|c|c|}
\hline \multirow[t]{2}{*}{ Variable } & \multirow[t]{2}{*}{ Aspects of Language Development } & \multicolumn{3}{|c|}{ Normality Test } \\
\hline & & Sig & Kolmogorov-Smirnov Z & Information \\
\hline \multirow{3}{*}{$\begin{array}{l}\text { Children's } \\
\text { Development }\end{array}$} & Literacy & 0855 & 0.820 & Normal \\
\hline & Receptive & 0.322 & 0.714 & Normal \\
\hline & Expressive & 0.432 & 0.767 & Normal \\
\hline \multirow[t]{4}{*}{ Ability to express opinions } & Clarity of Expressing Opinions & 0.481 & 0.679 & Normal \\
\hline & Able to communicate opinion & 0.640 & 0.566 & Normal \\
\hline & The content of the ideas is conveyed is logical & 0.799 & 0.873 & Normal \\
\hline & The ideas are conveyed coherently/systematically & 0.573 & 0.926 & Normal \\
\hline
\end{tabular}

Table IV: Normality Test Results

\section{B. Hypothesis Test Results Descriptive}

Table V: Descriptive Test Results

\begin{tabular}{|l|l|c|c|c|c|}
\hline \multirow{2}{*}{ Variable } & \multicolumn{1}{|c|}{ Aspects of Language Development } & \multicolumn{2}{c|}{ Pre-test } & \multicolumn{2}{c|}{ Post-test } \\
\cline { 2 - 6 } & & mean & St.dev & mean & St.dev \\
\hline \multirow{3}{*}{ Children's Language Development } & Literacy & 2.43 & 0.79 & 4.43 & 0.55 \\
\cline { 2 - 6 } & Receptive & 2.21 & 0.67 & 4.27 & 0.73 \\
\cline { 2 - 6 } & Expressive & 1.93 & 0.31 & 3.91 & 0.57 \\
\hline \multirow{3}{*}{ Ability to express opinions } & Clarity of Expressing Opinions & 2.49 & 0.37 & 4.29 & 0.65 \\
\cline { 2 - 6 } & Able to communicate opinion & 2.38 & 0.43 & 4.31 & 0.49 \\
\cline { 2 - 6 } & The content of the ideas conveyed is logical & 2.21 & 0.25 & 4.18 & 0.55 \\
\cline { 2 - 6 } & The ideas conveyed coherently/systematically & 2.19 & 0.49 & 3.87 & 0.61 \\
\hline
\end{tabular}

\section{t-test}

Table VI: T-Test Result

\begin{tabular}{|l|l|c|c|c|}
\hline \multirow{2}{*}{ Variable } & \multicolumn{1}{|c|}{ Aspects of Language Development } & \multicolumn{3}{c|}{ Paired Sample t-test } \\
\cline { 2 - 5 } & & Sig & t-count & Information \\
\hline \multirow{3}{*}{ Children's Language Development } & Literacy & 0.000 & 3,500 & Significant \\
\cline { 2 - 5 } & Receptive & 0.000 & 4.160 & Significant \\
\cline { 2 - 5 } & Expressive & 0.000 & 3.480 & Significant \\
\hline \multirow{3}{*}{ Ability to express opinions } & Clarity of Expressing Opinions & 0.000 & 3.100 & Significant \\
\cline { 2 - 5 } & Able to communicate opinion & 0.000 & 3.230 & Significant \\
\cline { 2 - 5 } & The content of the ideas conveyed is logical & 0.000 & 3,470 & Significant \\
\cline { 2 - 5 } & The ideas conveyed coherently/systematically & 0.000 & 2,780 & Significant \\
\hline
\end{tabular}

\section{DISCUSSION}

This study uses an experimental method that aims to improve language skills and the attitude of daring to express opinions in children through story telling with the help of pop up media. The children's language ability can be seen when the children are given the opportunity to continue the story that has been read by the teacher. Children are also given the 
opportunity to ask questions related to the content of the story. In this study, the research process was carried out with children's language development skills in aspects of literacy, receptive and expressive (pre-test). After given a pretest, the children will be given treatment using pop-up media; then, at the last meeting the researcher conducted a post-test to compare parenting skills before given treatment and after given treatment.

The result of this study is story telling assisted by pop-up media which has a significant influence on the language development abilities of early childhood. This is evidenced by the value of significant that is 0.00 which is smaller than the significant degree value of 0.05 , where the children can continue the story that has been told by the teacher. The average value of children's language development variables in the literacy aspect pre-test is 2.43, receptive is 2.21, and expressive is 1.93 . Besides, the post-test average value obtained for the literacy aspect is 4.43, receptive is 4.27, and expressive is 3.92 . Based on the result described, the percentage increase in language literacy development is $40 \%$, the percentage increase in receptive language development is $41.2 \%$, and the percentage increase in expressive language development is $39.6 \%$. The use of storytelling assisted by pop-up media in TK Laboratorium UM can improve language skills in children.

Story telling assisted by pop-up media also has a significant influence on children's courageous attitude in expressing their opinions. The attitude to argue can be seen from the clarity of the children's opinion, being able to communicate their own opinion, the content of the ideas conveyed is logical, and the ideas are conveyed in a coherent/systematic manner. The result of this study has a significant effect that story telling with the help of popup book media can increase the ability of children's courage to have an opinion. This is evidenced by the significant value of 0.00 which is smaller than the value of the significant test degree of 0.05 where children have clarity in expressing their opinions, are able to communicate their opinions, the contents of ideas are conveyed logically, and the ideas are conveyed coherently/systematically.

Based on the average result of the variable values in the pretest, the ability to express opinions on the aspect of clarity of opinion is 2.49 , able to communicate opinions 2.38, the content of ideas conveyed is logical 2.21, and ideas are conveyed coherently/systematically are 2.19. Besides, in the post-test the ability to express opinions on the aspect of clarity of opinion is 4.29 , able to communicate opinions is 4.31 , the content of the ideas conveyed is logical 4.18, and ideas are conveyed coherently/systematically 3.87. Based on the result described, the percentage increase in the variable of ability to express opinions on the aspect of clarity of opinion is $36 \%$, the percentage increase in the variable of ability to express opinions aspects of expressing opinions is $38.5 \%$, the percentage increase in the variable of ability to express opinions on the aspect of content presented logically is equal to $39.4 \%$, and the percentage increase in the ability to express opinions aspect conveyed coherently/systematically are $33.6 \%$. The result of this study is based on data analysis It has been found that story telling assisted by pop-up book media that can improve children's language skills and courageous attitude.

Language includes a means of communication that symbolizes thoughts and feelings when interacting with other people (45). In addition, with language, one can convey the message/intention to be conveyed to others so that others will understand what they convey. Therefore, language development in early childhood is important to develop. During the early childhood language development period, the children's brain development is experiencing the maximum ability to absorb language (46). By utilizing pop-up media as a means of storytelling, it can increase children's courage in speaking, revealing the contents 
of the stories they hear. When the teacher gives story telling assisted by pop-up media, children do not only hear a story but also learn about new vocabulary so that they can increase the their vocabulary. This is the most important component that supports children's language skills (47).

Opinion is the result of a person's thoughts or opinions. Dare to have an opinion means a person's ability to express his heart and feelings according to his thinking power as a form of responding to something (48). Based on this opinion, the implementation of pre-test, treatment, and post-test activities are improved by motivating children to think, express themselves, and communicate. The children will be able to develop the ability to express their own opinion through the stories they have heard. In this study, researchers developed language skills and an attitude to argue in early childhood using pop-up media in the form of stories. "pop-up book" is a learning media that has a variety of interesting looks and themes and has threedimensional elements in it and is specially designed (49). This media contains illustrated stories and has dimensions when the book pages are opened. Children will feel curious about the pictures on each page so that children pay more attention to the stories conveyed by the teacher (50). Media in the form of dimensional images is very suitable to be used in learning, especially to improve language skills and the attitude to think in children, because different images on each page will be able to attract children and have fun. The researcher chose story telling assisted by pop-up media because it presents pictures and interesting story designs so that it can attract children to follow and pay attention in learning, thereby training children's language skills. In addition, children can also express themselves by expressing their opinions regarding the contents of the stories they have heard.

The result of this study indicates that there is an effect of storytelling assisted by pop-up media to improve language skills and attitudes of courage to argue in children in TK Laoratorium UM, Malang City. This is indicated by significant increases in language skills and courage in early childhood who use storytelling assisted by pop-up media. The reason behind the increase is because story telling assisted by pop-up media can attract children's interest in participating in learning. In addition, attractive dimensional images on each page make children feel interested and willing to express their opinions in front of the class so that children's language skills also increase.

\section{CONCLUSION}

Based on research and data analysis that has been carried out and the results obtained, it can be concluded that there is a significant effect between storytelling assisted by pop-up media on improving language skills and the attitude to argue in early childhood. It can be seen from the increase in the average pre-test to post-test scores on language development and the ability to express children's opinions. In addition, the results of the t-test indicate the level of significance on all dimensions of the variable is $0.000<0.05$, where it means that storytelling assisted by pop-up media has the effect of increasing language skills and an attitude to express opinions in early childhood.

\section{Acknowledgement: None}

\section{Conflict of Interest: None}

\section{Source of Funding: None}

\section{REFERENCES}

1. Yafie E, Olufunke O-FT, Ali M, Robbaniyah I, Maulidia LN, Setyaningsih D. The Combination of Imaginative Teaching Methods and Multimedia Learning in Early Childhood Education during COVID Pandemic: Social-Emotional and Language Development. AL-ATHFAL J Pendidik ANAK. 2021 May; 7(1):1-14.

2. Tunmer WE, Hoover WA. Cognitive and Linguistic Factors in Learning to Read. Read Acquis. 2018 Oct;175-214.

3. Yafie E, Giavarini I, Maulidia LN. Stimulating Strategy Children Experiencing 
Late Language Emergence (LLE) During Pandemic Covid-19. In 2020.

4. Merritt DH, Klein S. Do early care and education services improve language development for maltreated children? Evidence from a national child welfare sample. Child Abuse Negl. 2015 Jan; 39:185-96.

5. García-Peñalvo FJ, Mendes AJ. Exploring the computational thinking effects in preuniversity education. Comput Human Behav. 2018 Mar;80:407-11.

6. Kuśnierek A. Developing students' speaking skills through role-play. World Sci News. 2015;7:73-111.

7. Magruder ES, Hayslip WW, Espinosa LM, Matera C. Many Languages, One Teacher: Supporting Language and Literacy Development for Preschool Dual Language Learners. 2013;

8. Genesee F. Myths about early childhood bilingualism. Can Psychol. 2015 Feb;56 (1):6-15.

9. Wei L. Dimensions of bilingualism. Biling Read. 2020 Jul;3-22.

10. Alsman S. The Importance of Intentional Language and Literacy Development in Early Childhood. Integr Stud. 2017 Jan;

11. Firmansyah D. Analysis Of Language Skills In Primary School Children (Study Development Of Child Psychology Of Language). PrimaryEdu-J Prim Educ. 2018 Feb;2(1):35-44.

12. Firyati YI, Haenilah E, sasmiati sasmiati. Story Telling Meningkatkan Perkembangan Bahasa Anak Usia Dini. J Pendidik Anak. 2016;2(2).

13. Kory J, Breazeal C. Storytelling with robots: Learning companions for preschool children's language development. IEEE RO-MAN 2014-23rd IEEE Int Symp Robot Hum Interact Commun Human-Robot CoExistence Adapt Interfaces Syst Dly Life, Ther Assist Soc Engag Interact. 2014 Oct;643-8.

14. Aisyah E, Iriyanto T, Astuti W, Yafie E. Pengembangan Alat Permainan Ritatoon Tentang Binatang Peliharaan Sebagai Media Stimulasi Kemampuan Kognitif Anak Usia Dini. J Kaji Teknol Pendidik. 2019;

15. Westlund JK, Breazeal C. The Interplay of Robot Language Level with Children's Language Learning during Storytelling. ACM/IEEE Int Conf Human-Robot Interact. 2015 Mar;02-05-Marc:65-6.
16. Florea NM, Hurjui E. Critical Thinking in Elementary School Children. Procedia - Soc Behav Sci. 2015 May;180:565-72.

17. Yafie E, Nirmala B, Kurniawaty L, Bakri TSM, Hani AB, Setyaningsih D. Supporting cognitive development through multimedia learning and scientific approach: An experimental study in preschool. Univers $\mathbf{J}$ Educ Res. 2020;

18. Lestari I, Lestari I. Developing Wordless Picture Book to Improve the Storytelling Ability of 5 to 6 Years Old Children. J Cakrawala Pendidik. 2018 Feb;37(1):30-41.

19. Setyarini S, Muslim AB, Rukmini D, Yuliasri I, Mujianto Y. Thinking critically while storytelling: Improving children's HOTS and English oral competence How to cite (in APA style. Indones J Appl Linguist. 2018;8(1):189-97.

20. Reason M, Heinemeyer C. Storytelling, story-retelling, storyknowing: towards a participatory practice of storytelling. http://dx.doi.org/101080/135697832016122 0247. 2016 Oct;21(4):558-73.

21. Lwin SM. Narrativity and creativity in oral storytelling: Co-constructing a story with the audience: http://dx.doi.org/101177/ 0963947016686602. 2017 Feb;26(1):34-53.

22. Cajete GA. Children, myth and storytelling: An Indigenous perspective: http://dx.doi.org/101177/204361061770383 2. 2017 Jun;7(2):113-30.

23. Interactive Books: Playful Media before Pop-Ups-Jacqueline Reid-Walsh-Google Buku.

24. Hidayati NN. Storytelling: One Package Learning In Improving Language Skill And Implanting Character Education On Children. EDUKASI J Pendidik Islam. 2019 Dec;7(2):53-72.

25. Hidayah AF. The Effect of Pop Up Book Activities On Group A's Early Childhood Creativity. Early Child Res J. 2020 Jul;3 (1):30-40.

26. Adelila S, Prawoto A. Learning Activities of Students using Developed Innovative Popup Book. Anal J Magister Psikol UMA. 2018 Dec;10(2):111-7.

27. Wahyunungsih S, Raharjo R, Azizah U. Development of Teaching Books Based on Science Pop Up To Train Critical Thinking Skills of Elementary Students. Int J Educ Vocat Stud. 2020 May;2(5).

28. Desmarais C, Sylvestre A, Meyer F, Bairati I, Rouleau N. Systematic review of the 
literature on characteristics of late-talking toddlers. Int J Lang Commun Disord. 2008; 43(4):361-89.

29. Whitehurst GJ, Lonigan CJ. Child Development and Emergent Literacy. Child Dev. 1998 Jun;69(3):848-72.

30. Luinge MR, Post WJ, Wit HP, GoorhuisBrouwer SM. The Ordering of Milestones in Language Development for Children From 1 to 6 Years of Age. 2006 Oct; 49 (5):92340.

31. Permendikbud. No. 137 Tahun 2014.

32. Dosman CF, Andrews D, Goulden KJ. Evidence-based milestone ages as a framework for developmental surveillance. Paediatrics and Child Health (Canada). 2012.

33. McCarthy D. Language development in the preschool child. Child Behav Dev A course Represent Stud. 2005 Aug;107-28.

34. Cawood AR. The relation between pedagogic text and pedagogic practice: a study of two grade seven science classes. 2011;

35. Dietrich KN, Succop PA, Berger OG, Keith RW. Lead exposure and the central auditory processing abilities and cognitive development of urban children: The cincinnati lead study cohort at age 5 years. Neurotoxicol Teratol. 1992 Jan;14(1):51-6.

36. Yafie E, Samah NA, Mohamed H, Haqqi YA. Collaborative mobile seamless learning (Cmsl) based on android apps to improving critical thinking in higher education in the post-covid-19 era. J Adv Res Dyn Control Syst. 2020;

37. Kasman N, Kaseng S, Hanafie SH, Daeng $\mathrm{K}$. The effectiveness of stimulus to the language acquisition of early age child. $\mathbf{J}$ Lang Teach Res. 2014;5(6):1315-21.

38. PARERA JD. Belajar Mengemukakan Pendapat. 1987;

39. Conti-Ramsden G, Durkin K. Language Development and Assessment in the Preschool Period. Neuropsychol Rev 2012 224. 2012 Jun;22(4):384-401.

40. Siregar R. Meningkatkan Kemampuan Mengemukakan Pendapat Siswa Menggunakan Model Time Token Pembelajaran Ips Kelas V Sekolah Dasar. 2018;
41. Polya G. How to Solve It: A New Aspect of Mathematical Method-G. Polya- Google Buku. 2004.

42. Hendrix SL. Popup Workshop: Computationally Enhanced Paper Engineering for Children. 1969;

43. Reid-Walsh J. Activity and Agency in Historical "Playable Media." http://dx.doi.org/101080/174827982011619 547. 2012 May;6(2):164-81.

44. Heo J, Han S, Koch C, Aydin H. Piaget"s Egocentrism and Language Learning: Language Egocentrism (LE) and Language Differentiation (LD). J Lang Teach Res. 2011;2(4):733-9.

45. Busch B. Expanding the Notion of the Linguistic Repertoire: On the Concept of Spracherleben-The Lived Experience of Language. Appl Linguist. 2017 Jun;38 (3):340-58.

46. Denboba AD, Sayre RK, Wodon QT, Elder LK, Rawlings LB, Lombardi J. Stepping Up Early Childhood Development : Investing in Young Children for High Returns. 2014;

47. Vaahtoranta E, Lenhart J, Suggate S, Lenhard W. Interactive Elaborative Storytelling: Engaging Children as Storytellers to Foster Vocabulary. Front Psychol. 2019 Jul;10(JULY):1534.

48. Williams P, Sheridan S, Sandberg A. Preschool-an arena for children's learning of social and cognitive knowledge. https://doi.org/101080/09575146201387260 5. 2014 Jan;34(3):226-40.

49. Sari NE, Suryana D. Thematic Pop-Up Book as a Learning Media for Early Childhood Language Development. J Pendidik Usia Dini. 2019 Apr;13(1):43-57.

50. Monoyiou E, Symeonidou S. The wonderful world of children's books? Negotiating diversity through children's literature. http://dx.doi.org/101080/136031162015110 2338. 2015 Jun;20(6):588-603.

How to cite this article: Kustiawan U, Yafie E. The effect of storytelling assisted by pop-up media to improve language development skills and attitude of opinion. International Journal of Research and Review. 2021; 8(8): 740-749. DOI: https://doi.org/10.52403/ijrr.20210897 